\title{
Continuous flow and the prothrombinase-catalyzed activation of prothrombin
}

Citation for published version (APA):

Schoen, P., Lindhout, T., Willems, G., \& Hemker, H. C. (1990). Continuous flow and the prothrombinasecatalyzed activation of prothrombin. Thrombosis and Haemostasis, 64(4), 542-547.

https://doi.org/10.1055/s-0038-1647354

Document status and date:

Published: 01/01/1990

DOI:

10.1055/s-0038-1647354

Document Version:

Publisher's PDF, also known as Version of record

\section{Please check the document version of this publication:}

- A submitted manuscript is the version of the article upon submission and before peer-review. There can be important differences between the submitted version and the official published version of record.

People interested in the research are advised to contact the author for the final version of the publication, or visit the DOI to the publisher's website.

- The final author version and the galley proof are versions of the publication after peer review.

- The final published version features the final layout of the paper including the volume, issue and page numbers.

Link to publication

\footnotetext{
General rights rights.

- You may freely distribute the URL identifying the publication in the public portal. please follow below link for the End User Agreement:

www.umlib.nl/taverne-license

Take down policy

If you believe that this document breaches copyright please contact us at:

repository@maastrichtuniversity.nl

providing details and we will investigate your claim.
}

Copyright and moral rights for the publications made accessible in the public portal are retained by the authors and/or other copyright owners and it is a condition of accessing publications that users recognise and abide by the legal requirements associated with these

- Users may download and print one copy of any publication from the public portal for the purpose of private study or research.

- You may not further distribute the material or use it for any profit-making activity or commercial gain

If the publication is distributed under the terms of Article $25 \mathrm{fa}$ of the Dutch Copyright Act, indicated by the "Taverne" license above, 


\title{
Continuous Flow and the Prothrombinase-Catalyzed Activation of Prothrombin
}

\author{
Pieter Schoen ${ }^{1}$, Theo Lindhout ${ }^{1}$, George Willems ${ }^{2}$, and H. Coenraad Hemker ${ }^{1}$ \\ From the Department of Biochemistry ${ }^{1}$, and the Cardiovascular Research Institute Maastricht ${ }^{2}$, \\ University of Limburg, Maastricht, The Netherlands
}

\begin{abstract}
Summary
The activation of prothrombin by prothrombinase was investigated in a continuous flow system at $25^{\circ} \mathrm{C}$. A glass capillary, containing a continuous phospholipid bilayer attached to the interior surface, was first perfused with factor Va. The factor Va bound to the phospholipid surface functioned as sites for the formation of prothrombinase, when subsequently a factor $\mathrm{Xa}$ and prothrombin containing solution was perfused. Under the conditions used, steady-state rates of prothrombin activation were attained after 4 to $15 \mathrm{~min}$. The rates of prothrombinase formation increased with increasing factor Xa concentrations and flow rates, which is compatible with the assembly of prothrombinase being dependent on the flux of factor $\mathrm{Xa}$ to the phospholipid-bound factor Va. As long as factor $\mathrm{Xa}$ and prothrombin were present in the fluid phase the assembly of prothrombinase was apparently irreversible; during at least $20 \mathrm{~min}$ no loss of activity occurred. The steady-state rate of prothrombin activation was dependent on the surface concentration of prothrombinase, at $1.0 \mu \mathrm{M}$ prothrombin and a shear rate of $82 \mathrm{~s}^{-1}$ the average rate was $870 \mathrm{~mol}$ thrombin/min per mol prothrombinase. In contrast to test tube experiments it was observed that in this flow system, the formation of $\alpha$-thrombin is favoured above the formation of meizothrombin (des fragment 1).
\end{abstract}

\section{Introduction}

In vivo blood coagulation is a complex process, which requires actions of and interactions between the vascular wall, blood platelets and the coagulation system. Of the coagulation system many reactions are membrane bound processes, i.e. they take place on either the platelet or endothelial cell membrane. Consequently, during coagulation reactants must be transported from the blood stream to the membrane surface. These transport processes, and therefore the formation and activities of the membrane-bound enzymatic complexes, are dependent on the local flow conditions $(1,2)$.

Recently it has been pointed out by Gemmell et al. (3) that the progress of coagulation reactions during flow cannot be extrapolated from static, closed systems. They reported on the activation of factor X by membrane-bound tissue factor and factor VII(a), during flow, and found that the steady-state catalytic activity of the enzymatic complex is independent of the concentration of factor VII(a) in the fluid phase. In addition it was shown, that the factor VII(a) concentration in the perfused solution determined the time required to achieve the steady-state.

\section{Abbreviations:}

ATIII, antithrombin III; p-NPGB, p-nitrophenyl p'-guanidinobenzoate hydrochloride; HSA, human serum albumin; S2238, D-phenylalanylL-pipecolyl-L-arginine-p-nitroanilide dihydrochloride.

Correspondence to: Dr. Th. Lindhout, Department of Biochemistry, University of Limburg, P.O. Box 616, 6200 MD Maastricht, The Netherlands
In the past, detailed studies have been published on the kinetics and mechanisms of prothrombin activation (see refs. 4 and 5, and references therein), however, they were all performed in systems where the dynamic aspects of flow could not be examined. Prothrombinase, a key enzymatic complex in blood coagulation, is a dissociable $\mathrm{Ca}^{2+}$-dependent enzymatic complex, composed of the enzyme factor $\mathrm{Xa}$, the non-enzymatic cofactor factor Va, and a suitable phospholipid surface. This complex is a highly efficient activator of prothrombin, which leads to the formation of thrombin. In this paper, we describe the activation of prothrombin by prothrombinase under well-defined flow conditions, obtained by perfusion of reactants through a phospholipid coated glass capillary.

\section{Materials and Methods}

\section{Capillaries}

Glass capillaries with an internal diameter of $0.58 \mathrm{~mm}$ and a length of $12.7 \mathrm{~cm}$, were obtained from Brand, FRG. They were boiled for $30 \mathrm{~min}$ in $2 \mathrm{mg} / \mathrm{ml}$ Sparkleen (Fisher Scientific Co., Pittsburgh, USA). After extensive washing with deionized water the capillaries were placed overnight in a $30 \%$ chromic acid solution. The capillaries were then again extensively washed and kept in $50 \%$ ethanol. Capillaries were used the same day; prior to use they were dried.

\section{Proteins and Phospholipid Vesicles}

Bovine factor $\mathrm{V}$ and factor Va (6) and bovine prothrombin (7) were prepared and quantified as described. Bovine antithrombin III (ATIII) was isolated as reported previously (8). Human prothrombin was purified as described (9), and the molar concentration was determined, after complete activation with Echis carinatus venom (Sigma), by active site titration with p-NPGB (10). Human factor Xa was prepared by activation of purified factor $X$ (11) with the factor $X$ activating protein from Russell's Viper venom (KabiVitrum, Stockholm, Sweden) and isolated as described for the bovine protein (12). The molar concentration was determined by active site titration with p-NPGB (13).

Meizothrombin (des fragment 1) was prepared as follows. Human prothrombin $(16 \mu \mathrm{M})$ was activated by Echis carinatus venom $(0.5 \mathrm{mg} / \mathrm{ml})$ in $50 \mathrm{mM}$ Tris- $\mathrm{HCl}(\mathrm{pH} 7.5)$ containing $100 \mathrm{mM} \mathrm{NaCl}, 10 \mathrm{mM} \mathrm{CaCl}_{2}$, and $10 \mathrm{mM}$ benzamidine- $\mathrm{HCl}$. After $5 \mathrm{~min}$ the conversion of prothrombin was terminated by the addition of EDTA to a final concentration of $20 \mathrm{mM}$, and the mixture was applied to a column $(1.5 \times 30 \mathrm{~cm})$ of QAESepharose (Pharmacia) equilibrated in $50 \mathrm{mM}$ Tris- $\mathrm{HCl}(\mathrm{pH} \mathrm{7.5}$ ), $100 \mathrm{mM} \mathrm{NaCl}$, and $10 \mathrm{mM}$ benzamidine- $\mathrm{HCl}$ at $4{ }^{\circ} \mathrm{C}$. A linear salt gradient, from 0.10 to $0.60 \mathrm{M} \mathrm{NaCl}$ in $50 \mathrm{mM}$ Tris- $\mathrm{HCl}$ (pH 7.5), $10 \mathrm{mM}$ benzamidine- $\mathrm{HCl}(2 \times 150 \mathrm{ml})$, was applied and meizothrombin (des fragment 1), assessed by its activity on S2238, eluted at about $0.25 \mathrm{M}$ $\mathrm{NaCl}$. The fractions with the highest activity were pooled. In these steps, the presence of $10 \mathrm{mM}$ benzamidine- $\mathrm{HCl}$ was an absolute requirement; upon its omission the only product was $\alpha$-thrombin. For further use, the benzamidine was rapidly removed by gel filtration. The preparation was applied to a column $(1.6 \times 60 \mathrm{~cm})$ of Sephadex G50 (Pharmacia) in $50 \mathrm{mM}$ Tris- $\mathrm{HCl}\left(\mathrm{pH} \mathrm{7.9)}, 175 \mathrm{mM} \mathrm{NaCl}\right.$ at $4{ }^{\circ} \mathrm{C}$. Fractions were immediately pooled and stored at $-70^{\circ} \mathrm{C}$. The final preparation was over $95 \%$ pure as judged by SDS polyacrylamide gelelectrophoresis (14), and the concentration of meizothrombin (des fragment 1) was assessed by active site titration with p-NPGB (10). 
Small unilaminar vesicles, composed of $75 \%$ egg phosphatidylcholine and $25 \%$ brain phosphatidylserine were prepared by sonication in $50 \mathrm{mM}$ Tris- $\mathrm{HCl}$ ( $\mathrm{pH} 7.5$ ) containing $100 \mathrm{mM} \mathrm{NaCl}$ (7). To determine amounts of phospholipid covering the inner wall of the capillaries, also vesicles were prepared with tracer concentrations of dioleoylphosphatidyl- $\left({ }^{14} \mathrm{C}\right)$ serine (specific activity $2.0 \mathrm{GBq} / \mathrm{mmol}$; Amersham, UK). The vesicle suspension had a specific activity of $97.8 \mathrm{MB}$ /mmol. Radioactivity measurements were performed with a Beckman LS3801 scintillation counter, utilizing a liquid scintillation cocktail (Formula-989., Biotechnology systems, Boston, USA).

\section{The Activation of Prothrombin by Surface-Bound Prothrombinase}

Capillaries were coated with phospholipid, by $20 \mathrm{~min}$ incubation with a $1 \mathrm{mM}$ vesicle suspension, and then rinsed with Tris-buffer $(50 \mathrm{mM}$ Tris$\mathrm{HCl}[\mathrm{pH} 7.9]$ containing $175 \mathrm{mM} \mathrm{NaCl}, 3.0 \mathrm{mM} \mathrm{CaCl}$, and $0.5 \mathrm{mg}$ ovalbumin/ml) at a flow rate of $1.2 \mathrm{ml} / \mathrm{min}$ (wall shear rate $1,044 \mathrm{~s}^{-1}$ ) for $2 \mathrm{~min}$. The capillaries were then perfused with factor Va, diluted in the Tris-buffer, for $10 \mathrm{~min}$ at a flow rate of $30 \mu 1 / \mathrm{min}$ (wall shear rate $26 \mathrm{~s}^{-1}$ ). Immediately hereafter the capillaries were washed with Tris-buffer at a flow rate of $30 \mu \mathrm{l} / \mathrm{min}$ during $10 \mathrm{~min}$, and then perfused with a solution of factor Xa and prothrombin in the same Tris-buffer. Drops were collected at the outlet and $20 \mu \mathrm{l}$ aliquots were immediately diluted in $430 \mu \mathrm{l}$ of $50 \mathrm{mM}$ Tris- $\mathrm{HCl}(\mathrm{pH} \mathrm{7.9}), 175 \mathrm{mM} \mathrm{NaCl}, 20 \mathrm{mM}$ EDTA, containing $0.5 \mathrm{mg} \mathrm{HSA} / \mathrm{ml}$ and assayed for thrombin by the addition of $50 \mu \mathrm{l}$ chromogenic substrate (S2238, KabiVitrum, Stockholm, Sweden). The final concentration S2238 was $0.22 \mathrm{mM}$ and the rate of absorbance increase was recorded at $405 \mathrm{~nm}$ on a dual wavelength spectrophotometer (reference wavelength: $500 \mathrm{~nm}$ ) at $37^{\circ} \mathrm{C}$. The amounts of thrombin formed were calculated from a standard curve constructed with purified human $\alpha$-thrombin (15) under identical conditions.

All perfusions were performed by the use of a syringe pump (Harvard Apparatus Co., Massachusetts, USA) resulting in a continuous laminar flow through the capillaries. The experiments were performed in a climated room at $25 \pm 1^{\circ} \mathrm{C}$, and the conditions mentioned were routinely applied, unless otherwise indicated.

\section{Determination of Factor Va Bound to the Phospholipid Coated Capillaries}

At the end of each experiment the capillaries were emptied and subsequently washed with one capillary volume of $0.2 \%$ Triton X100 in $50 \mathrm{mM}$ Tris- $\mathrm{HCl}$ (pH 7.9), $175 \mathrm{mM} \mathrm{NaCl}, 3.0 \mathrm{mM} \mathrm{CaCl}$. The solutions were mixed and a sample was diluted 10 -fold with Tris-buffer, and assayed for factor Va.

\section{Factor Va Assay}

Factor Va samples $(10 \mu \mathrm{l})$ were added to cuvettes, containing a solution of factor Xa, phospholipid vesicles and $\mathrm{CaCl}_{2}$ in $50 \mathrm{mM}$ Tris- $\mathrm{HCl}$ (pH 7.9), $175 \mathrm{mM} \mathrm{NaCl}$, and $0.5 \mathrm{mg} \mathrm{HSA} / \mathrm{ml}$. After $2 \mathrm{~min}$ at $37^{\circ} \mathrm{C}, 10 \mu \mathrm{l}$ bovine prothrombin was added. The final concentrations were $0.10 \mathrm{nM}$ factor Xa, $10 \mu \mathrm{M}$ phospholipid, $10 \mathrm{mM} \mathrm{CaCl}_{2}$, and $0.2 \mu \mathrm{M}$ prothrombin in a final volume of $125 \mu \mathrm{l}$. After $5 \mathrm{~min}$ the conversion of prothrombin was terminated by the addition of $325 \mu \mathrm{l}$ of $50 \mathrm{mM}$ Tris- $\mathrm{HCl}(\mathrm{pH} 7.9)$, $175 \mathrm{mM} \mathrm{NaCl}, 20 \mathrm{mM}$ EDTA, and $0.5 \mathrm{mg} \mathrm{HSA} / \mathrm{ml}$. Hereafter, $50 \mu \mathrm{l}$ $2.2 \mathrm{mM}$ S2238 was added and the amount of thrombin formed was determined. The amounts of thrombin formed were linearly dependent on the amounts of factor Va present, up to at least $2.0 \mathrm{pM}$ factor Va in the assay.

In samples derived from the capillaries, $0.01 \%$ Triton X100 was present. Because the assay was sensitive to such an amount of Triton X100, factor Va reference curves were constructed in the presence of the same detergent concentration. Each factor Va determination was performed in duplicate, and the differences between the individual values of each duplicate varied between zero and approximately $10 \%$ of the mean values.

\section{Measurement of Meizothrombin (Des Fragment 1)}

Samples $(20 \mu 1)$ from drops collected at the capillary outlet, were immediately diluted in cuvettes, containing $430 \mu \mathrm{l}$ of $50 \mathrm{mM}$ Tris- $\mathrm{HCl}$ (pH 7.9), $175 \mathrm{mM} \mathrm{NaCl}, 20 \mathrm{mM}$ EDTA, $0.5 \mathrm{mg}$ HSA $/ \mathrm{ml}, 4 \mathrm{nM}$ ATIII, and $2 \mu \mathrm{g}$ unfractionated heparin/ml (165 USP U/mg) at $37^{\circ} \mathrm{C}$. After
$1 \mathrm{~min} 50 \mu 12.2 \mathrm{mM} \mathrm{S} 2238$ was added and the residual amidolytic activity was determined. From previous work it follows that under these conditions $\alpha$-thrombin activity will be completely neutralized, whereas this is not the case for meizothrombin (des fragment 1 ) activity (8). The amounts of meizothrombin (des fragment 1 ) present in the samples were calculated from the residual amidolytic activities utilizing a standard curve constructed with purified meizothrombin (des fragment 1 ).

\section{Theory of Protein Adsorption to the Interior Surface of a Capillary}

During laminar flow along the inner wall of a capillary, in which a fluid phase protein binds to the capillary wall, the transfer of the protein occurs in a thin diffusion layer between the bulk solution and the surface. It has been derived (16) that, provided the binding capacity of the surface is sufficiently large as compared to the protein content of the boundary layer, and if the binding sites are uniformly distributed, the rate of protein flow $\left(v_{\mathrm{S}}, \mathrm{mol} \mathrm{cm}^{-2} \mathrm{~s}^{-1}\right)$ towards the surface is given by:

$v_{S}=0.54\left(\gamma D^{2 / x}\right)^{1 / 3} S_{b}$

where $\gamma$ is the shear rate $\left(\mathrm{s}^{-1}\right)$, D is the diffusion coefficient of the protein $\left(\mathrm{cm}^{2} / \mathrm{s}\right), \mathrm{x}$ is the distance from the capillary entrance $(\mathrm{cm})$, and $\mathrm{S}_{\mathrm{b}}$ is the concentration of protein in the fluid phase $(\mathrm{mol} / \mathrm{ml})$. The shear rate is given by:

$\gamma=32 \mathrm{Q} /\left(\pi \mathrm{d}^{3}\right)$

where $Q$ is the flow rate $(\mathrm{ml} / \mathrm{s})$, and $\mathrm{d}$ is the internal diameter $(\mathrm{cm})$ of the capillary.

\section{Results}

\section{Determination of the Amounts of Phospholipid Bound to the Interior Surfaces of Capillaries}

It has been demonstrated that; when glass coverslips are placed in a vesicle suspension, the coverslip surface becomes covered with a continuous, planar membrane (17). This technique has been used for the binding of phospholipids to glass capillaries (3). We used virtually the same technique, and in order to verify the formation of a phospholipid bilayer we determined the amounts of phospholipid bound, by use of vesicles containing ${ }^{14} \mathrm{C}$-labelled phosphatidylserine. Clean and dry capillaries were filled with a suspension of the small unilaminar phospholipid vesicles, as outlined in "Materials and Methods". Non-bound phospholipid was removed by perfusion of Tris-buffer at a flow rate of $1.2 \mathrm{ml} /$ $\mathrm{min}$ for $2 \mathrm{~min}$. The capillaries were emptied, washed with approximately $0.5 \mathrm{ml}$ of scintillant and broken into 3 segments. All was collected in a vial containing scintillant to a final volume of $5 \mathrm{ml}$ and the radioactivity was measured.

Our results showed that $6.5 \times 10^{-10} \mathrm{~mol}$ phospholipid was bound per $\mathrm{cm}^{2}\left(\mathrm{n}=8 ; \mathrm{SD}=0.6 \times 10^{-10} \mathrm{~mol} / \mathrm{cm}^{2}\right)$. Such an amount of phospholipid agrees reasonably well with published data (ref. 3, and references therein). In addition, we demonstrated the bilayer to be stable. After the removing of non-bound phospholipid, capillaries were perfused for $10 \mathrm{~min}$ with $0.15 \mathrm{nM}$ factor Va followed by a $30 \mathrm{~min}$ perfusion with Tris-buffer at a rate of $30 \mu \mathrm{l} / \mathrm{min}$. The amount of radioactivity retained in the capillaries, assessed as described above, corresponded with $5.9 \times$ $10^{-10} \mathrm{~mol} / \mathrm{cm}^{2}\left(\mathrm{n}=4 ; \mathrm{SD}=0.9 \times 10^{-10} \mathrm{~mol} / \mathrm{cm}^{2}\right)$ phospholipid bound to the capillary surfaces.

We also established, with the use of the ${ }^{14} \mathrm{C}$-labelled vesicles, that the procedure for the determination of the amounts of factor Va bound to the phospholipid surfaces, removed essentially all bound phospholipid. Again capillaries were filled with the vesicle suspension, and washed as described. Then each capillary was emptied in a vial containing $5 \mathrm{ml}$ of scintillant and washed with one volume of the Tris-buffered Triton X100 solution. By this procedure we recovered an amount of radioactivity corresponding to $6.2 \times 10^{-10} \mathrm{~mol}$ phospholipid $/ \mathrm{cm}^{2}(\mathrm{n}=4 ; \mathrm{SD}=$ $0.1 \times 10^{-10} \mathrm{~mol} / \mathrm{cm}^{2}$ ). 


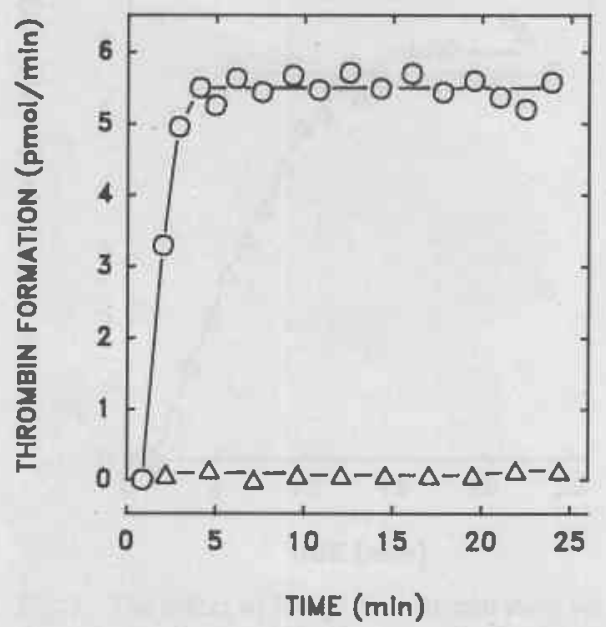

Fig, 1 The rate of thrombin formation as function of time. Prothrombin $(1.0 \mu \mathrm{M})$ and factor $\mathrm{Xa}(0.50 \mathrm{nM})$ were perfused through a phospholipid coated capillary in the presence of $2.4 \mathrm{fmol}$ factor $\mathrm{Va} / \mathrm{cm}^{2}(0)$, or a capillary which was not coated with phospholipid $(\Delta)$. See the text for further experimental details

\section{Binding of Factor Va to Phospholipid-Coated Capillaries}

In order to obtain surface-bound prothrombinase we first adsorbed factor Va to phospholipid coated capillaries. To this end, a phospholipid-coated capillary was perfused with $0.15 \mathrm{nM}$ factor Va for $10 \mathrm{~min}\left(30 \mu \mathrm{l} / \mathrm{min}\right.$; wall shear rate $\left.26 \mathrm{~s}^{-1}\right)$ and subsequently washed for $10 \mathrm{~min}$ with buffer $(30 \mu \mathrm{l} / \mathrm{min})$. The amount of factor Va bound to the phospholipid-coated capillary, determined as outlined in "Materials and Methods", was $2.4 \mathrm{fmol} / \mathrm{cm}^{2}$. Given the interior surface of the capillary $\left(2.31 \mathrm{~cm}^{2}\right)$ and the factor Va influx $(300 \mu \mathrm{l}$ of $0.15 \mathrm{nM})$ it can be calculated that $12 \%$ of the amount of factor Va perfused became bound. We investigated the distribution of the factor Va bound to the phospholipid surface, by breaking a capillary, perfused with factor Va and washed with buffer, into two pieces of approximately equal length. An amount of $2.6 \mathrm{fmol}$ factor Va was bound in the inlet part $(I=6.4 \mathrm{~cm})$ and $2.1 \mathrm{fmol}$ in the outlet part of the capillary $(1=6.3 \mathrm{~cm})$; hence the ratio of the amounts is $1: 0.81$.

\section{The Course of Thrombin Generation by Surface-Bound Prothrombinase}

Fig. 1 shows thrombin generation obtained by the perfusion of $0.50 \mathrm{nM}$ factor $\mathrm{Xa}$ and $1.0 \mu \mathrm{M}$ prothrombin at a flow rate of $94 \mu 1 / \min$ (wall shear rate $82 \mathrm{~s}^{-1}$ ), after a phospholipid-coated capillary had been perfused with a solution of $0.15 \mathrm{nM}$ factor Va for $10 \mathrm{~min}$. It is seen that under these conditions thrombin is measurable at the outlet after about $1 \mathrm{~min}$. Then the rate of thrombin formation rapidly increases until a steady-state rate of approximately $5.5 \mathrm{pmol} / \mathrm{min}$ is obtained, which takes about $4 \mathrm{~min}$. The steady-state thrombin formation is stable for at least $20 \mathrm{~min}$, which could suggest that during the course of the perfusion with factor $\mathrm{Xa}$ and prothrombin no significant amount of factor $\mathrm{Va}$ is eluted from the phospholipid coated capillary. In order to verify this we determined the amount of bound factor $\mathrm{Va}$, at the end of the perfusion with factor Xa and prothrombin, and found $2.5 \mathrm{fmol} / \mathrm{cm}^{2}$. An amount which is identical to the amount of factor $\mathrm{Va}$ bound at the onset of the perfusion with factor $\mathrm{Xa}$ and prothrombin, as determined in the previous section.

The observed thrombin formation is truly the consequence of prothrombinase-catalyzed activation of prothrombin because in

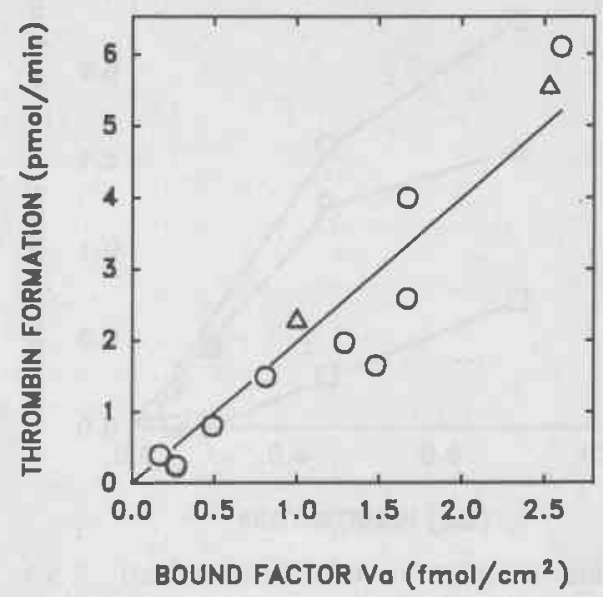

Fig. 2 The steady-state thrombin formation as function of the amount of bound factor Va. Phospholipid-coated capillaries were perfused with factor $\mathrm{Va}$ solutions of variable concentration. Steady-state rates of thrombin formation were determined at fluid phase concentrations of $1.0 \mu \mathrm{M}$ prothrombin and either $0.05 \mathrm{nM}(O)$ or $0.50 \mathrm{nM}(\triangle)$ factor $\mathrm{Xa}$ at a flow ratc of $94 \mu \mathrm{l} / \mathrm{min}$

the absence of phospholipids thrombin generation was not detectable (Fig. 1). Also when the factor Va perfusion step was omitted thrombin activity was not measurable. Thus, factor Xa alone did not produce thrombin at detectable rates whether phospholipids were present or not.

\section{The Steady-State Rate of Thrombin Formation as Function of the Amount of Phospholipid-Bound Factor Va}

We were intrigued by the stable steady-state rate of thrombin formation, and we were curious to find out to what extent the steady-state was a measure for the amount of surface-bound prothrombinase. Thus we varied the amount of factor Va bound, which was achieved by varying the factor Va concentration of the perfused solution. Subsequently we determined the steady-state rates of thrombin formation by perfusion of factor $\mathrm{Xa}$ and prothrombin.

The results, shown in Fig. 2, demonstrate that the steady-state rate of thrombin formation increases linearly with the amount of bound factor $\mathrm{Va}$ up to $2.5 \mathrm{fmol}$ factor $\mathrm{Va} / \mathrm{cm}^{2}$. It is also seen that the steady-state levels are independent of the fluid phase factor Xa concentration when it varies from 0.05 to $0.50 \mathrm{nM}$. In this range of factor $\mathrm{Xa}$ concentrations the phospholipid-bound factor Va can thus be saturated with factor Xa irrespective of the concentration of the latter. Linear regression analysis of the data revealed that $1 \mathrm{fmol}$ factor $\mathrm{Va} / \mathrm{cm}^{2}$ results in a steady-state rate of thrombin formation of $2.0 \pm 0.1(\mathrm{SE}) \mathrm{pmol} / \mathrm{min}$. With an interior capillary surface of $2.31 \mathrm{~cm}^{2}$, thrombin is thus generated with a rate of $870 \pm 40 \mathrm{~mol} / \mathrm{min}$ per mol prothrombinase.

The Influence of the Fluid Phase Factor Xa Concentration and the Flow Rate on the Rate of Generation of Prothrombinase

Although, the steady-state level of prothrombinase activity is not influenced by the fluid phase factor Xa concentration, the formation rate of prothrombinase decreases drastically with decreasing factor Xa concentrations, which is shown in Fig. 3.

In the presence of $0.50 \mathrm{nM}$ factor $\mathrm{Xa}$ thrombin generation starts at about $1 \mathrm{~min}$ and reaches the steady-state at approximately $4 \mathrm{~min}$. In the presence of $0.05 \mathrm{nM}$ factor $\mathrm{Xa}$ thrombin generation starts at roughly the same time, however, it takes 


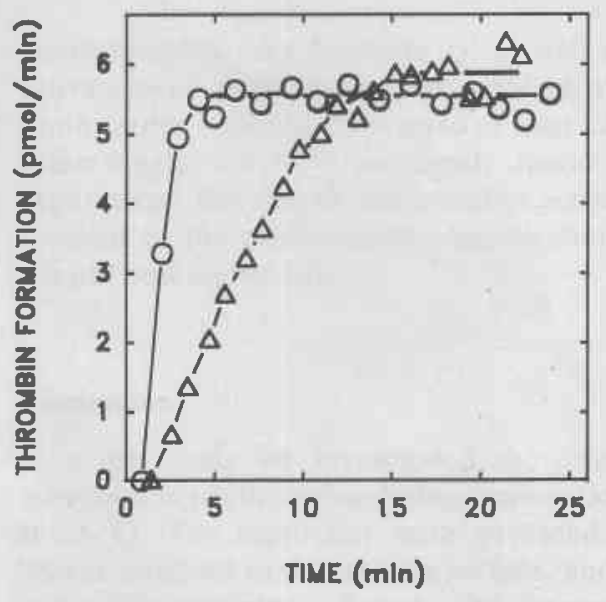

Fig. 3 The effect of factor Xa concentration on the course of the rate of thrombin formation. Capillaries containing phospholipid-bound factor Va were perfused with $1.0 \mu \mathrm{M}$ prothrombin and factor $\mathrm{Xa}$ at $94 \mu \mathrm{l} / \mathrm{min}$. The experiments were conducted with $0.50 \mathrm{nM}$ factor $\mathrm{Xa}$ and 2.5 fmol factor $\mathrm{Va} / \mathrm{cm}^{2}(O)$ or $0.05 \mathrm{nM}$ factor Xa and $2.6 \mathrm{fmol}$ factor $\mathrm{Va} / \mathrm{cm}^{2}(\triangle)$

about $15 \mathrm{~min}$ before the steady-state is reached. At the steadystate thrombin was generated at an average rate of $5.8 \mathrm{pmol} / \mathrm{min}$ by approximately $6.0 \mathrm{fmol}$ prothrombinase. The first derivatives of the curves reveal that at the onset of thrombin, its rate of formation increases with $5.3 \mathrm{pmol} / \mathrm{min}$ per min and $0.60 \mathrm{pmol} /$ min per min at 0.50 and $0.05 \mathrm{nM}$ factor $\mathrm{Xa}$, respectively. Thus, after the lag-phase prothrombinase activity is generated at a rate of $5.5 \mathrm{fmol} / \mathrm{min}(0.50 \mathrm{nM}$ factor $\mathrm{Xa})$ and $0.62 \mathrm{fmol} / \mathrm{min}(0.05 \mathrm{nM}$ factor $\mathrm{Xa}$ ).

The rate of formation of prothrombinase is also influenced by the flow rate. This is seen in Fig. 4, where thrombin formation was studied at a flow rate of $48.4 \mu \mathrm{l} / \mathrm{min}$ (wall shear rate $42 \mathrm{~s}^{-1}$ ). Thrombin generation now starts at approximately 2 min and reaches a steady-state end-level at $7 \mathrm{~min}$, and the prothrombinase activity is generated at a rate of $2.6 \mathrm{fmol} / \mathrm{min}$.

Steady-State Rates of Generation of $\alpha$-Thrombin and Meizothrombin (Des Fragment 1) at Varying Prothrombin Concentrations

When prothrombin activation by prothrombinase is monitored via amidolytic activity measurements we cannot discriminate $\alpha$ thrombin and meizothrombin (des fragment 1) as the products

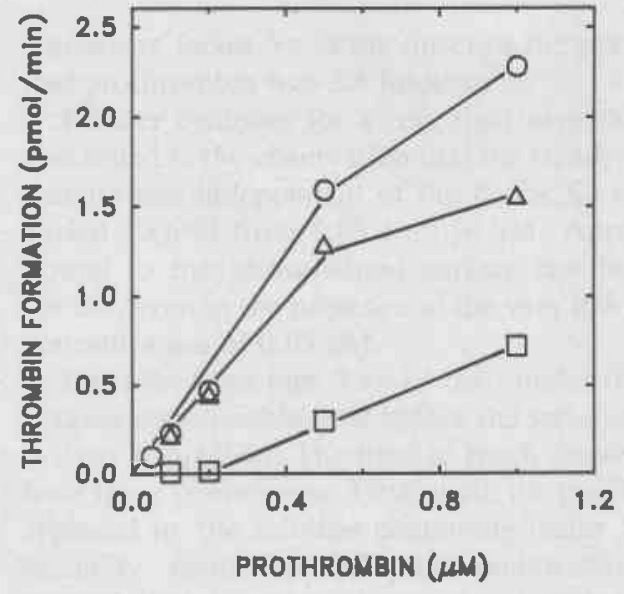

Fig. 5 The steady-state rate of thrombin formation as function of the prothrombin concentration. Prothrombin was activated by $0.05 \mathrm{nM}$ factor $\mathrm{Xa}$ in the presence of $1.9 \mathrm{fmol}$ factor $\mathrm{Va} / \mathrm{cm}^{2}$ at a flow rate of $30 \mu \mathrm{l} /$ min. The amounts of total amidolytic thrombin activity $(O)$, as well as the amounts of $\alpha$-thrombin $(\triangle)$ and meizothrombin (des fragment 1 ) ( $\square$ ) formed were determined

formed. It has been shown in static, closed systems that, depending on the prothrombin concentration, large amounts of meizothrombin (des fragment 1) are formed during prothrombin activation by complete prothrombinase $(4,8)$. Therefore, we investigated whether the formation of meizothrombin (des fragment 1) also occurs in our continuous flow system.

We assayed the amidolytic thrombin activity determined at the capillary outlet for the presence of meizothrombin (des fragment 1 ). This was achieved by taking advantage of the fact that $\alpha$ thrombin is rapidly scavenged by ATIII in the presence of heparin, whereas the inhibition of meizothrombin (des fragment 1 ) by ATIII is slow and is not enhanced by heparin (8). The steady-state rates of $\alpha$-thrombin and meizothrombin (des fragment 1) formation as function of the fluid phase prothrombin concentration are depicted in Fig. 5. Our data show, that up to $0.20 \mu \mathrm{M}$ prothrombin no significant amounts of meizothrombin (des fragment 1) are formed; when the prothrombin concentration increases further up to $1.0 \mu \mathrm{M}$ the relative amount of meizothrombin (des fragment 1) formed increases up to $32 \%$. In addition, the steady-state rates of formation of overall thrombin activity ( $\alpha$-thrombin plus meizothrombin [des fragment 1]) are linearly dependent on the prothrombin concentration up to $0.50 \mu \mathrm{M}$ of prothrombin. A deviation from linearity is seen when the prothrombin concentration increases to $1.0 \mu \mathrm{M}$. Thus during continuous flow the relative rates of formation of $\alpha$-thrombin and

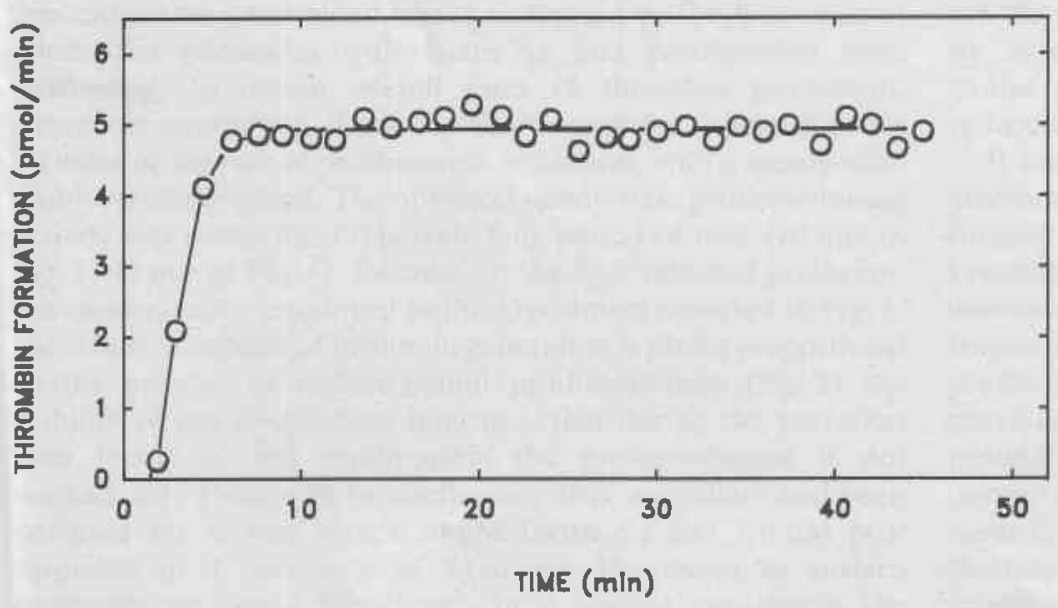

Fig. 4 Time course of the thrombin generation rate. Prothrombin $(1.0 \mu \mathrm{M})$ and factor $\mathrm{Xa}(0.50 \mathrm{nM})$ were perfused at a flow rate of $48.4 \mu 1 / \mathrm{min}$ through a factor Va containing phospholipid coated capillary. The amount of factor Va was $3.3 \mathrm{fmol} / \mathrm{cm}^{2}$ 
meizothrombin (des fragment 1), as well as the overall rates of activation of prothrombin are dependent on the fluid phase prothrombin concentration up to at least $1.0 \mu \mathrm{M}$ of prothrombin. Interestingly, we have previously found that, in vesicle type experiments the rate of prothrombin activation is virtually independent of the prothrombin concentration at concentrations of $0.6 \mu \mathrm{M}$ and higher (8).

\section{Discussion}

In this study we investigated the prothrombinase-catalyzed activation of prothrombin during laminar flow through capillaries, at $25^{\circ} \mathrm{C}$. The capillaries were provided with a phospholipid bilayer attached to the interior surface, and then perfused with a factor Va containing solution. The amount of bound factor Va was determined after washing, and we found that significant amounts of factor $\mathrm{Va}$ were retained. A factor $\mathrm{Va}$ influx of $0.15 \mathrm{nM}$ at a flow rate of $30 \mu \mathrm{l} / \mathrm{min}$ for $10 \mathrm{~min}$ resulted in a $12 \%$ factor Va binding of $2.4 \mathrm{fmol} / \mathrm{cm}^{2}$. It has been reported that factor Va-binding to phospholipid vesicles, composed a $20-25 \%$ phosphatidylserine and 75-80\% phosphatidylcholine, is satured at a phospholipid to protein ratio $(\mathrm{mol} / \mathrm{mol})$ varying between 57 and $100(18,19)$. Phospholipid vesicles are highly curved, however, relative to the molecular dimensions of proteins, the phospholipid bilayer attached to a capillary can be regarded as a plane. Since maximum surface concentration (factor $\mathrm{V}$, factor $\mathrm{X}$, prothrombin) seems to be independent of the curvature of the surface (20), it can be estimated, from the factor Va-binding data $(18,19)$ and the amount of phospholipid bound to the capillaries $(6.5 \times$ $10^{-10} \mathrm{~mol} / \mathrm{cm}^{2}$ ), that under the conditions used, less than $0.04 \%$ of the maximum factor Va binding capacity was used.

At such a low surface concentration the adsorption of factor $\mathrm{Va}$ is limited by the diffusion-dependent flux of factor $\mathrm{Va}$ towards the surface (20). In which case, according to eq. I, the adsorption of factor $\mathrm{Va}$ in a given time should decrease for increasing distances from the tube entrance. Thus, the inlet part of a capillary should contain a significant higher amount of factor Va as compared to the outlet part. We investigated the distribution of the bound factor Va by breaking a capillary into two pieces of equal length. The observed distribution was almost homogeneous $(1: 0.81)$. A full explanation for the apparent deviation from theory is not yet at hand, however, it can be speculated that the phospholipid-bound factor Va can diffuse laterally across the surface, as has been described for lipid-bound antibodies in phospholipid monolayers (21).

Factor Va containing phospholipid-coated capillaries were perfused with factor $\mathrm{Xa}$ and prothrombin, drops were collected at the capillary outlet and assayed for thrombin. The thrombin concentrations determined where multiplied by the flow rates at which the perfusions with factor $\mathrm{Xa}$ and prothrombin were performed, to obtain overall rates of thrombin generation. Thrombin generation showed a short lag-phase followed by an increase of the rate of prothrombin activation, until a steady-state end-level was reached. The obtained steady-state prothrombinase activity was stable for a relatively long period of time $(20 \mathrm{~min}$ in Fig. 1, 40 min in Fig. 4). Because, at the flow rate and prothrombin concentration employed in the experiment depicted in Fig. 1, the steady-state rate of thrombin generation is direct proportional to the amount of surface-bound prothrombinase (Fig. 2) the stability of the steady-state indicates, that during the perfusion with factor $\mathrm{Xa}$ and prothrombin the prothrombinase is not washed out. This could be confirmed; after a capillary had been perfused for $25 \mathrm{~min}$ with $0.50 \mathrm{nM}$ factor $\mathrm{Xa}$ and $1.0 \mu \mathrm{M}$ prothrombin at a flow rate of $94 \mu 1 / \mathrm{min}$, the factor Va surface concentration was $2.5 \mathrm{fmol} / \mathrm{cm}^{2}$. In a control experiment the amount of factor $\mathrm{Va}$ at the onset of the perfusion with factor Xa and prothrombin was $2.4 \mathrm{fmol} / \mathrm{cm}^{2}$.

Further evidence for a very tight assembly of prothrombinase was found in the observation that the steady-state prothrombinase activity was independent of the factor $\mathrm{Xa}$ concentration when it varied 10 -fold from 0.05 to $0.50 \mathrm{nM}$. Apparently the factor Va bound to the phospholipid surface can be saturated with factor $\mathrm{Xa}$, even in the presence of the very low fluid phase factor $\mathrm{Xa}$ concentration of $0.05 \mathrm{nM}$.

It is seen from Figs. 3 and 4 that, under the specific conditions, it takes considerable time before the steady-state prothrombinase activity is reached. The time to reach steady-state depends on at least three phenomena. First of all, the capillary content has to be replaced by the solution containing factor $\mathrm{Xa}$ and prothrombin, secondly, factor Xa and prothrombin have to be transferred through the boundary layer to the phospholipid surface, and thirdly, the thrombin formed has to move from the catalytic sites into the bulk solution in order to leave the capillary.

The rate of formation of prothrombinase depended on the fluid phase factor Xa concentration and the flow rate. At a flow rate of $94 \mu \mathrm{l} / \mathrm{min}$ and in the presence of $0.05 \mathrm{M}$ factor Xa the rate of formation of prothrombinase was $0.62 \mathrm{fmol} / \mathrm{min}$, with $0.50 \mathrm{nM}$ factor $\mathrm{Xa}$ the rate was $5.5 \mathrm{fmol} / \mathrm{min}$ (Fig. 3). At a flow rate of $48.4 \mu 1 / \mathrm{min}$, in the presence of $0.50 \mathrm{nM}$ factor $\mathrm{Xa}$ the rate of formation of prothrombinase was $2.6 \mathrm{fmol} / \mathrm{min}$ (Fig. 4). Because the prothrombin concentrations were at least 2,000-times in excess over the factor $\mathrm{Xa}$ concentrations, the diffusion limited rate of transport of prothrombin to the phospholipid surface is at least 3 orders of magnitude higher than the diffusion limited rate of transport of factor $\mathrm{Xa}$ to the surface. Therefore it is well feasible that under these conditions, the time delay required to reach the steady-state prothrombinase activity is dependent on the flux of factor $\mathrm{Xa}$ to the phospholipid-bound factor Va. According to eqs. I and II (Materials and Methods) the diffusion controlled transfer of factor $\mathrm{Xa}$ to the surface indeed increases with increasing fluid phase factor $\mathrm{Xa}$ concentrations and flow rates.

We have previously demonstrated, that if factor $\mathrm{Xa}$ is present as part of the fully assembled prothrombinase, a significant amount of meizothrombin (des fragment 1) is formed (8). The first step in the formation of this product is the generation of meizothrombin. Meizothrombin is formed when prothrombin is specifically cleaved at only one of the factor Xa-cleavage sites present in prothrombin. This cleavage has as consequence that the thrombin active site becomes exposed. Meizothrombin is very rapidly processed further, and gives rise to the formation of meizothrombin (des fragment 1). Meizothrombin (des fragment 1) is a "dead-end" product, because the protein, lacking the phospholipid- and $\mathrm{Ca}^{2+}$-binding regions, is not as good a substrate for the prothrombinase as prothrombin is. Moreover its reactivity, as compared with thrombin, towards macromolecular substrates, e.g. fibrinogen, antithrombin III, and factor V, is greatly reduced.

It has been shown in static, closed systems, that the relative amounts of $\alpha$-thrombin and meizothrombin (des fragment 1) formed depend on the prothrombin concentration $(4,8)$. In keeping with these findings we observed, that also during continuous flow, the relative contribution of meizothrombin (des fragment 1) to the total amidolytic activity increases when the prothrombin concentration increases. However, in contrast to previous work $(8)$, where at $1.0 \mu \mathrm{M}$ prothrombin $84 \%$ of the product was meizothrombin (des fragment 1 ), we observed that during flow the relative amount of meizothrombin (des fragment 1) formed is diminished to $32 \%$. Apparently, during flow the major prothrombin activation product is $\alpha$-thrombin instead of meizothrombin (des fragment 1). 


\section{Acknowledgement}

We thank Ron Blezer for preparing meizothrombin (des fragment 1).

\section{References}

1 Goldsmith H L, Turitto V T. Rheological aspects of thrombosis and haemostasis: basic principles and applications. Thròmb Haemostas 1986; 55: 415-35.

2 Leonard E F. Rheology of thrombosis. In: Hemostasis and Thrombosis; Basic Principles and Clinical Practice, 2nd edition. Colman R W, Hirsh J, Marder V J, Salzman E W (eds). JB Lippincott Company, Philadelphia 1987; pp 1111-22.

3 Gemmell C H, Turitto V T, Nemerson Y. Flow as a regulator of the activation of factor $\mathrm{X}$ by tissue factor. Blood 1988; 72: 1404-6.

4 Rosing J, Tans G. Meizothrombin, a major product of factor Xacatalyzed prothrombin activation. Thromb Haemostas 1988; 60: $355-60$.

5 Tracy P B. Regulation of thrombin generation at cell surfaces. Sem Thromb Hemostas 1988; 14: 227-33.

6 Lindhout T, Govers-Riemslag J W P, vd Waart P, Hemker H C, Rosing J. Factor Va-factor Xa interaction. Effects of phospholipid vesicles of varying composition. Biochemistry 1982; 21: 5494-502.

7 Rosing J, Tans G, Govers-Riemslag J W P, Zwaal R F A, Hemker H C. The role of phospholipid and factor $\mathrm{Va}$ in the prothrombinase complex. J Biol Chem 1980; 255: 274-83.

8 Schoen $\mathrm{P}$, Lindhout $\mathrm{T}$. The in situ inhibition of prothrombinaseformed human $\alpha$-thrombin and meizothrombin (des F1) by antithrombin III and heparin. J Biol Chem 1987; 262: 11268-74.

9 Hendrix H, Lindhout T, Mertens K, Engels W, Hemker H C. Activation of human prothrombin by stoichiometric levels of staphylocoagulase. J Biol Chem 1983; 258: 3637-44.

10 Chase T, Shaw E. Comparison of the esterase activities of trypsin, plasmin and thrombin on guanidinobenzoate esters. Titration of the enzymes. Biochemistry 1969; 8: 2212-24.
11 Mertens K, Bertina R M. Pathways in the activation of human coagulation factor X. Biochem J 1980; 185: 647-58.

12 Lindhout T, Kop-Klaassen B H M, Hemker H C. Activation of decarboxyfactor $\mathrm{X}$ by a protein from Russell's viper venom purification and partial characterization of activated decarboxyfactor X. Biochim Biophys Acta 1978; 533: 327-41.

13 Smith R L. Titration of activated bovine factor X. J Biol Chem 1973; 248: $2418-23$.

14 Laemmli U K. Cleavage of structural proteins during the assembly of the head of bacteriophage T4. Nature 1970;227: 680-5.

15 Miller-Andersson M, Gaffney P J, Seghatchian M J. Preparation and stability of a highly purified human thrombin standard. Thromb Res 1980; 20: 109-22.

16 Bird R B, Stewart W E, Lightfoot E N. Transport Phenomena. John Wiley \& Sons, Inc., New York 1960; pp 46-363.

17 Brian A A, McConnell H M. Allogenic stimulation of cytotoxic T cells by supported planar membranes. Proc Natl Acad Sci USA 1984; 81 : $6159-63$.

18 Higgins D L, Mann K G. The interaction of bovine factor $\mathrm{V}$ and factor V-derived peptides with phospholipid vesicles. J Biol Chem 1983; 258: 6503-8.

19 vd Waart P, Bruls H, Hemker H C, Lindhout T. Interaction of bovine blood clotting factor $\mathrm{Va}$ and its subunits with phospholipid vesicles. Biochemistry $1983 ; 22: 2427-32$.

20 Hermens W T, Kop J M M, Willems G M. Adsorption of coagulation factors II, V, and $\mathrm{X}$ at phospholipid membranes. In: Coagulation and Lipids. Zwaal R F A (ed). CRC Press, Inc., Boca Raton 1988; pp 73-97.

21 Subramaniam S, Seul M, McConnell H M. Lateral diffusion of specific antibodies bound to lipid monolayers on alkylated substrates. Proc Natl Acad Sci USA 1986; 83: 1169-73.

Received December 29, 1989 Accepted after revision July 23, 1990 